\title{
МОДУСИ ПЕРЕМІЩЕНЬ В ПИСЬМІ ПРО СЕБЕ ФІКЦІЙНОГО СУБ'ЄКТА
}

\section{Юлія Юхимівна Павленко}

\author{
https://orcid.org/0000-0002-4128-122X \\ pavlenkoyulia1@gmai.com \\ доктор філологічних наук, доцент,
}

кафедра теорії та історії світової літератури імені професора В. І. Фесенко,

Київський національний лінгвістичний університет

\begin{abstract}
Анотація. У статті висвітлюються результати дослідження модусів переміщення в художньому тексті, дієгезис якого є письмом про Себе героя роману. Взяті до уваги франиузькі романи від Просвітництва до сучасності дозволили пояснити переміщення в діахронічному вимірі тексту-письма франиузької літератури принципів організації художнього ландщафту, створеного особистісним письмом фікиійного суб'єкта. Ще один модус переміщення дозволив проявити аналіз руху протагоністів на сюжетно-фабульному рівні: мандрівки, блукання персонажів розглянуті у метафоричному полі. В контексті теми конструювання ідентичності суб 'єкта переміщення на рівні оповіді виявили свою конструктивну природу. Положення проведеного дослідження ілюструються на матеріалі текстів різних культурно-історичних епох: Е. Фромантена (романтизм), Ф. Моріака (модернізм), Д. Пенака, П. Кіньяра, А.-Д. Гарі, А. Маалуфа.

Ключові слова: письмо про Себе; перемішення; подорож; франиузький роман; фікиійний суб'єкт; һото scribens; Моріак; Пенака; Кіньяр; Гарі; Маалуфа.
\end{abstract}

Письмо про Себе ніколи не знало браку уваги — як з боку наукової думки, так і з боку літературної критики, проте концепт «переміщення» ще не набув необхідного аналітичного наповнення у цьому дискурсивному полі. Концепти «Я» та «письмо» перехрещувались в психоаналітичних та філософсько-антропологічних дослідженнях, що у висновках обов'язково експлікували потужну силу процесу самописання суб' єкта на шляху до самопізнання. Студії, в яких особистісне письмо посідало чільне місце, мали на меті глибший аналіз структур людської психіки, засобів збереження минулого, формування досвіду, стосунку процесу творчості до зовнішнього боку життя, зв'язків людини 3 мовою. Наголос на одному 3 цих аспектів обов'язково призводив до порушення й усіх інших питань або відсилання до них, тож можна стверджувати, що особистісне письмо як предмет аналізу є фігурною дужкою цілого комплексу важливих тем. Перебуваючи на перетині різних наук, індивідуальне письмо про «Я» послуговується досягненнями і психоаналізу, і філософії, і літературознавства. Спільним маркером усіх студій про письмо стає широке використання метафор у мові дослідження, що природно мало призвести до розгляду письма про Себе у площині художньої літератури.
Вивчення зразків особистісного письма проектує дослідження широкого кола питань, серед яких головними постають екзистенційно-психологічні особливості письма про Себе, «Я» автора та розповідь про пережите як мовні конвенції, особливості рефлексії суб'єкта письма, жанрова палітра егодокументів, лексико-стилістична специфіка окремих форм письма.

Метод мікрочитання, який запропонував Ж.-П. Рішар, дає можливість змінити масштаб літературознавчої мапи художнього ландшафту i розглянути окремі деталі як мікрорепрезентацію прихованої природи письма. Естетична робота героя французького роману, що виступає в амплуа homo scribens, 3 боку художньої літератури підтверджує думку, розгорнуту в «Мікрочитаннях II» Рішара, про те, що письмо завжди є поштовхом, імпульсом, тропізмом [11, с. 55]. Для опису роботи тексту тематичні критики в числі перших використовують, як правило, метафори руху. Для пояснення роботи письма та ії особливостей в дієгезисі метафори руху (серед яких базовою $є$ переміщення) підходять якнайкраще, оскільки передають / звільняють природу письма. Механізм оперування методом мікрочитання скеровує дослідження до занурення в текст з метою пошуку образів, що можуть стати такими метафорами письма. 
Текст-письмо XVIII ст. багато в чому виконуе роль донора у генетикоконтактних зв'язках французького роману. Роман «Юлія, або Нова Елоїза» Руссо для письма про Себе героїв наступних епох має підстави зайняти місце претексту в аспекті вибудови комунікативної арки (зокрема, єдності адресата та адресанта у просторі письма), влади письма над автором, перетворення образів зовнішньої дійсності на метафори внутрішнього світу, розгортання письма як маршруту самопізнання суб'єкта. Роман «Небезпечні зв'язки» Лакло логічно визначити як претекст ігрового начала текступисьма, мультиспрямованості комунікативної арки. «Черниця» Дідро, своєю чергою, виступатиме претекстом наступних зразків у аспекті творення ресурсами письма нового тіла, пористості жанрових модусів особистісного письма. Роман «Історія сучасної грекині» Прево - претекст такої грані тексту-письма як неоднозначність правди / вигадки (мотиву осмислення щирості / брехні), а також такого вектора комунікативної арки як діалог герояоповідача із зовнішнім гіпотетичним читачем.

Текст-письмо французького романтизму на перший план вивів сповідальну модальність, аргументовану зануренням суб'єкта розповіді в глибини власного внутрішнього світу. Практика письма героя-романтика стає способом визначення смислу життя, яке ще не завершене. Письмо про Себе дозволяс уникнути нестерпної для романтика зупинки, яка $є$ необхідною умовою погляду в дзеркало $з$ метою пізнання. Інакше кажучи, герой Констана, Мюссе, Гюго письмом долає свій головний романтичний конфлікт: письмо зупиняє рух життя, не перериваючи його, множить часові пласти, відкриває нові можливості, завдяки чому перетворюється на іншопростір.

Письмо про Себе фікційного суб'єкта епохи літературного модернізму, відкидаючи багато в чому здобутки попередніх культурних парадигм, водночас увиразнило вимисел як грань роботи письма. Художній простір текстів-письма цього періоду позбавлений вказівок, за якими читач міг би розрізнити правду про життя героя від брехні. Реалізація естетичної роботи героя-просвітника та героя-романтика як фікційних суб'єктів письма містила цілий комплекс елементів, що працювали на досягнення ефекту реальності та формування довіри зовнішнього читача до предмета виписування. Серед арсеналу цих засобів зворотне листування, в якому відповідь адресата $€$ множенням точок зору та, відповідно, засобом об’єктивізації історії адресанта; передмова екстра- дієгетичного суб’єкта, що була містком між реальною дійсністю зовнішнього читача та світом фікції, утвореним письмом героя. Ефект реальності та стилізація письма фікційних суб'єктів під документ 3 реальної дійсності мали за мету передання досвіду від героя до читача. Натомість у письмі героя Ж.-П. Сартра, С. де Бовуар, Ф. Моріака, Ж. Бернаноса, Жульєна Грака, А. Жіда, М. Юрсенар, Л.-Р. Дефоре, Ж. Батая, С. Бекета навіть за умови наявності передмови ніщо не порушує фікційної природи роботи homo scribens, не кидає тінь на письмо як вимисел. На контрасті $з$ письмом фікційних суб'єктів попередніх культурно-історичних періодів текст-письмо епохи літературного модернізму увиразнює стирання дистанції між героєм та реципієнтом, неможливість надання читачу поради, поготів передачі сформованого досвіду. Письмо героя модернізму нівелює інформацію, що пов'язана 3 необхідністю правдоподібності, натомість дух оповіді, мистецтво якої репрезентує homo scribens, позбавлений цієї залежності, повністю занурений у вимисел, що звільняе смисли внутрішніх імпульсів суб'єкта. Естафету в цьому питанні переймають герої-оповідачі роману рубежу XX-XXI ст.

У світлі постмодерністської гри в тексті і з текстом стали можливі фікціоналізація тих деталей, які раніше апріорі вважалися документальними (ім’я автора, топографія тощо). Підпис «Е. Ф.» під передмовою до твору «Одне літо в Сахарі» може за бажанням читача як відсилати до особи первинного автора, так і сприйматися як деталь фікційного простору за аналогією до ситуації з передмовою роману XVIII ст., коли автор вводив себе у твір обов'язково під маскою видавця, редактора тощо. Фікціоналізація автора у просвітницькому романі працювала на формування в читача довіри до вигаданих героїв. Металепсис уможливлював зрівняння у правах вигаданих та реальних суб'єктів за принципом: щоб читач вірив у реалістичність героїв, автор мусить представити себе у фікційному амплуа (Руссо в передмовах та ремарках до роману «Юлія, або Нова Елоїза» представляв себе як видавця, редактора, що перебуває на крок ближче до листів героїв, ніж читач; Прево в «Історія кавалера де Грійє та Манон Леско» — як зустрічного, якому герой розповів свою історію; Лакло - як збирача листів героїв тощо). Опис роботи письма у передмові до «Одного літа в Сахарі» несе важливі доповнення для пояснення багатьох питань, що розгортаються в цій роботі, знехтувати ними лише на підставі біографічного начала (оскільки в дискурсі оповідача вгадуються парале- 
лі 3 життям реального Ежена Фромантена) було б помилкою. «Гра у правду» (про яку пише Лежен в «Автобіографічному пакті») автора та читача передбачає рівність учасників творчого акту. Фромантен використав комплекс елементів, що надають історії у творі «Одне літо в Сахарі» документальності (підпис, рік, місто). Водночас передмова, паратекстуальні деталі якої працюють на формування у читача віри у правдивість історії, містить низку контраргументів пріоритетності документального начала. Оповідач зазначає, що пише історію, перебуваючи далеко від місця описуваних подій і в географічному, і в часовому аспекті, що допомагає йому відтворити минулі події виключно пам'ять, і саме ці обставини (більше, ніж будь-які інші випробування) надали йому можливості зрозуміти, «в чому істина мистецтва, яке надихається природою, що нам дає сама природа і чим іiї наділяє наша чуттєвість». Шукає істину оповідач «не в точності та суворій копії», які він вважає «другорядним фактором в творі такого жанру». Особливість «такого жанру» полягає в напрузі між досягненням документальності та підкресленням того факту, що «мистецтво проникло в оповідь». За таких обставин читач володіє достатньою кількістю аргументів, щоб на власний розсуд обрати напрямок конвенції, багатовекторність якої закладена самим автором. У межах фікціонального пакту текст Фромантена може бути підданий теоретичному абстрагуванню, у тому числі бути задіяним в координатах літературознавчого дослідження письма про Себе у французькому романі. Це ж стосується і «Подорожі на Схід» Ж. де Нерваля.

Приклад роману «Планета мавп» (1963р.) П'єра Буля засвідчує серйозне ставлення у французькій культурі до розрізнення між масовою та інтелектуальною літературою. Екранізація роману стала класикою світового кінематографу, але текст не посів гідного місця в історії французького роману. І хоча роман П. Буля містить рукопис фікційного суб’єкта Уліса Меру («Я довіряю цей рукопис Всесвіту не для того, щоб закликати на допомогу. Сдина моя надія, що моя розповідь, можливо, зуміє запобігти жахливій загрозі, що нависла над родом людським...» [3, с. 7]), якому відведено більшу частину романного простору, у цій роботі його не зараховано до корпусу текстів французького роману, в яких представлено письмо про Себе фікційного суб' єкта. Роль письма в романі «Планета мавп» може бути прокоментована у контексті романів Жуля Верна, які містять маркери письма героя. Втім, романи «20 000 льє під водою» та «Подорож до центру Землі», будучи одними 3 найвідоміших текстів наукової фантастики, у діалозі з іншими текстами-письмом фікційного суб'єкта здатні проявити метафорику глибини, і цим значно збагатити уявлення про фігури письма, натомість локус рукопису в романі «Планета мавп» окрім претензії на ефект реальності іншого повідомлення не несе.

Відношення між суб'єктом письма та історією, яку він продукує, $є$ тим проблемним полем, у якому переміщення виявляє себе особливо виразно, а тому вимагає детального аналізу. Ф. Лежен вказує на відмінність між пактом автобіографічним та романним, розкриваючи аргументовано природу першого. У ситуації письма про Себе фікційного суб'єкта відбувається своєрідне накладання двох пактів. Від автобіографічного контракту письмо героя-оповідача отримує ефект збудження реального читача (збуджує зацікавленість, довіру, пряме включення, спонукає думати про Себе). Ситуація з письмом фікційного суб'єкта позбавлена конфлікту, описаного в Ф. Лежена, суть якого полягає у відсутності логіки поєднання між реальністю людини, яка пише, $\mathrm{i}$ вигадкою в ії щоденнику чи іншому виді письма. За переконанням Лежена, вигадане життя, описане в щоденнику, є брехнею перед іншими та повним безглуздям стосовно себе самого [7]. У континуумі, що має назву дієгезис, поняття правди та вигадки переосмислюються у порівнянні 3 життям реальної людини - зазнає семантичного переміщення. Вигадана героєм-оповідачем історія може глибше розкрити внутрішній світ протагоніста, ніж чітко структурована історія його зовнішнього життя. Виписана історія легендарного героя (наприклад, в «Скелі Таніоса» Аміна Маалуфа) може стати правдою внутрішніх пошуків фікційного суб'єкта письма. Діалектика достовірності описаного та правдивості свідчення про Себе утворює ще одне проблемне поле, в якому особливості письма героя як рушійної сили роману здатні проявитися більш повно.

Цікавим винятком $з$ оминання традиції письма героя художнього твору як маркера літературного періоду другої половини XIX ст., що увійшов до істоpiï французького роману як позначений орієнтацією на раціоналізм та науковість, є два романи Жуля Верна. Письмом героя-оповідача Ж. Верн надає достовірності зображуваній історії в романах «Подорож до центру Землі» (1864) та «20 000 льє під водою. Навколосвітня подорож в морських глибинах» (1870), чим яскраво засвідчує потужність письма як засобу створення ефекту реальності, закріплену епістолярним романом Просвітництва. Пан Аронікс 
закінчує свою розповідь словами: «Хіба не жив я десять місяців його надзвичайним життям? Вже три тисячі років тому Еклезіаст поставив таке питання: “Хто міг колись виміряти глибину безодні?”. Але дати на це відповідь з усіх людей мають право лише двоє: капітан Немо і Я» [12]. Новим нюансом роботи фікційного суб'єкта у творах Ж. Верна є те, що герой не так прагне переконати інших у достовірності своєї історії, як надати певності самому собі. У реалізації цього бажання письмо про Себе допомагає і як слід, і як комунікативна ситуація. Неймовірні пригоди героїв Ж. Верна відображено в письмі пана Аронікса, що надає їм підтвердження, а також виходять на рівень діалогу суб'єкта письма зі собою (персонажем пережитої історії) та 3 зовнішнім реципієнтом. Маркери письма в романах Ж. Верна містяться в кінці творів, на роботу письма протягом розгортання художнього ландшафту ніщо не вказує. Отримуючи у фіналі роману вказівку на те, що вся попередня історія $\epsilon$ продуктом письма фікційного суб'єкта (очевидця подій), читач потрапляє в пастку тексту, адже усі попередні конвенції щодо рецепції твору виявляються порушеними - утверджується особливий вид відкритого тексту. Саме заява герояоповідача, притримана до останньої сторінки, про письмо як власну естетичну роботу запускає механізм поетики твору в русі [5].

Зіставний аналіз французьких романів, художній простір яких визначено роботою письма hото scribens, дозволяе окреслити коло найчастіше повторюваних та оригінально виражених мотивів i дискурсів, що розгортаються у тексті-письмі. Виходячи 3 мети цього дослідження, зупинитися варто на тих дискурсивних питаннях, що безпосередньо пов'язані із процесом конструювання ідентичності суб'єкта. Художній простір письма про Себе фікційного суб'єкта спонукає визначити іманентними йому такі проблемні поля: тіло, подорож, дім.

Письмо про Себе як діяльність, процес та модус розгортання історії передбачає вмотивованість людської поведінки. Використовуючи аристотелівську термінологію, що встановлювала залежність між праксисом та проайресисом (здатністю людини обміркувати результати своєї поведінки), Барт назвав код дій та вчинків проайретичним. 3 метою наближення до художньої своєрідності та семантичного значення письма про Себе фікційного суб' єкта доцільно проаналізувати акціональний код homo scribens, виділивши родові назви найважливіших рядів дій героя, що пише: мандрівки, пошуку дому, формування нового тіла. Саме ці дискурси проявляють переміщення в письмі про Себе фікційного суб'єкта - як на на сюжетно-фабульному рівні, так і на рівні оповіді.

Єдність дискурсу подорожі та дискурсу письма аргументована спільним семантичним полем названих концептів. Всі семантичні регістри цих двох тем зводяться до головної проблеми - конструювання суб'єктом самоідентичності. Розгортання подорожі, як і розгортання письма, має вихідною точкою приховану чи експліковану потребу індивіда в самовизначенні. Подорож, як і письмо, має відкритий горизонт. Неможливість вичерпання руху подорожі, як і практики письма, зумовлена поєднанням в їхній динаміці зовнішнього простору з внутрішнім виміром суб'єктивності.

У письмі перехрещуються характеристики різних модусів подорожі, що не дозволяє ототожнити процесуальність письма виключно з одним типом мандрів. При зіставленні регістрів письма 3 ключовими елементами модусів подорожі можна виділити певні семантичні єдності. Оскільки письмо корелює з заглибленням суб'єкта в себе, воно тим самим перехрещується 3 внутрішньою мандрівкою, і його корелятом може виступати уявна подорож. Цей жанр подорожі реалізується в процесі письма одразу двома значеннями: як рух у просторі уяви і як вигадана мандрівка. Як і у варіантах творів золотого віку уявної подорожі (Д. Дефо «Робінзон Крузо», Дж. Свіфт «Мандри Гуллівера», Вольтер «Кандід»), письмо на рівні історії не мусить відповідати реаліям зовнішнього життя автора (бути міметичним у вузькому розумінні). Письмо є реалізацією мандрівки уяви автора.

Як подорож передбачає єдність мандрівника та шляху, так письмо - єдність суб'єкта 3 його естетичною роботою. Але мета подолати простір, яку ставить перед собою людина у варіанті зовнішньої мандрівки, не може 3'явитися у варіанті роботи письма (герої Батая та Бекета виводять на поверхню руйнацію, спростовують семантичне навантаження провідних концептів письма в історії французького роману, але навіть ці інтенції не можуть прирівнюватися до бажання подолати простір письма). Суб'єкт письма А. Д. Гарі «S, або Надія на життя» метатекстуальною силою алюзій акцентує письмо як внутрішню мандрівку. Свої блокнотики герой Гарі називає записами, які він робив, «як письменник Асорін, вечорами в прохолоді постоялих дворів, на старих дорогах, що зберегли сліди Дона Кіхота» [9, с. 180]. Порівняння історії виникнення блокнотиків (що слугують протописьмом для роботи homo scribens pома- 
ну Гарі) з історією праці Асоріна над «Дорогою Дона Кіхота» дає ключ до пояснення мандрівки суб'єкта письма в « $\mathrm{S}$, або Надія на життя». Подорож Асоріна у пошуках координат маршруту героя Сервантеса переводила вигадку у реальність, а праця, що вмістила результати мандрівки, включала портрети людей, $з$ якими спілкувався письменник під час своïх пошуків. Дорога героя Гарі не має чітких координат маршруту зовнішньої подорожі: Париж і СанСебастьян позбавлені в письмовій історії фікційного суб'єкта конкретики. Париж для героя, насамперед, місце розгортання подій що стали спогадами, а Сан-Себастьян - місце для письма. Зважаючи на зв'язок Давида Алехандро (героя подій, що стали спогадами) і Декого із СанСебастьяна (того, хто може виписати історію минулого), можна стверджувати про відсутність дороги між цими двома місцями. Не виявляється можливим і розділити ці топоніми на реальний, зовнішній та уявний, вигаданий - місце письма та місце пам'яті входять один в один, міцно зав'язуючи вузол екзистенції протагоніста, вигадку та реальність у просторі письма. За таких умов нівелюється зовнішня подорож і виростає за своїм значенням внутрішня мандрівка - в часі, у спогади без хронології. Процес письма дозволяє наближатися до травматичного спогаду, розкладаючи його на літери: у героя в пам'яті спливають початкові букви дорогих серцю імен, що дозволяють створювати портрети близьких людей і в такий спосіб рухатися від спогаду до спогаду, вибудовуючи маршрут письма як внутрішньої подорожі. Саме ця внутрішня подорож у глибини пам'яті стає розгортанням дії письма, дозволяє зустрітися різним іпостасям героя Гарі, поєднати його «Я» 3 собою самим. Тож письмо у цьому варіанті підтверджує свою силу як прокладання суб'єктом дороги до Себе, створення ландшафту мандрівки, а не подолання простору як у зовнішній подорожі.

Новий тип мандрівки пов'язується 3 новим типом письма в історії героя Маалуфа, а тому простеження за розгортанням його подорожі є одним iз способів наблизитися до особливості роботи письма за принципом: зовнішня подорож - це ланцюг означників письма як внутрішньої мандрівки (позначуваного).

Історія письма героя Маалуфа за своїм включенням у життєві пошуки Бальдасара багато у чому перегукується 3 досвідом подорожі героя-просвітника. Герой Маалуфа повторює стратегію мандрівки у двох вимірах: зовнішню подорож здійснює його тіло, внутрішню - дух. Віддзеркалення у просто- рі письма зовнішньої мандрівки сприймається як умова пізнання смислів усіх подій, що мають місце в подорожі, та гармонізації «Я» героя, що відірвався від коріння та мандрує різними континентами, 3 собою самим. У зовнішньому світі герой спрямовує подорож свого письма (мандрує неодмінно зі щоденником, а, втрачаючи один зошит, одразу заводить новий). Таким чином щоденник подорожує з Бальдасаром як його незмінний супутник. Водночас, письмо апріорі не може займати пасивне місце в історії героя, який сам підтверджує рівність прав та можливостей - своїх та письма. «Я володію пером, а воно володіє мною; воно веде мене, а я - його». Герой Маалуфа не повторює думку про зрадливість пера (вперше в історії фікційного суб'єкта письма французького роману висловлену героїнею Руссо в романі «Юлія, або Нова Елоїза»): перо не може в його свідомості виступати зрадником, адже воно (як метонімія роботи письма) виконує для нього функцію того єдиного іншого, що є завжди близьким. Заглиблюючись у роботу письма, що з часів епістолярної практики героя-просвітника виступає еквівалентом внутрішньої мандрівки, герой втрачає «лідерську» позицію та добровільно підкорюється своєму перу.

3 наміром вписати Себе в історію, що «стане змістом книжки ціною в три франки, в дешевій палітурці», починає свою роботу письма після переїзду до Парижа герой Моріака «Старосвітський хлопчина». Для об'єктивного погляду на пережите він потребує дистанціювання від Себе у будь-який 3 можливих способів. Перед тим, як відкрити ресурси письма як оповіді у цьому процесі, Ален звертається до найбільш дієвого, зрозумілого та очевидного способу - він не може писати про всі болючі події та ситуації, наближатися до примирення зі собою в просторі, що став координатами усіх його помилок, тому змінює родинний маєток у Мальтаверне на Париж. Траєкторія письма героїв Моріака («Гадючник», «Старосвітський хлопчина») умовно закінчується метафорою валізи, в яку герої складають свої записи. Символічно, що усі вони з цієї валізкою їдуть до Парижа (як і Рокантен з «Нудоти» Сартра, а героїня «Зломленої» С. де Бовуар не виїжджає 3 Парижа). Таким чином, валіза передає багаж досвіду, утворений ревізією активної індивідуальної пам'яті, необхідний для досягнення успіху, ідею якого втілює Париж. У варіанті Алена успіх, перш за все, пов'язаний з реалізацією замисленого проекту письма («за цю історію відповідаю лише я ..., лише я зможу простежити, щоб з неї не зникла ані крупинка, щоб не зникло ані крупинки юності, не схожої на 
усі інші»). Аленове записування топографічних реалій Парижа на початку нового етапу роботи над майбутньої книжкою про Себе пояснюється природнім бажанням суб'єкта письма задати координати власного існування. Елементи урбаністичного простору, що має свою мапу, тобто володіє усталеною структурованістю, вселяють у суб'єкта, який приступає до роботи письма, якщо не впевненість, то принаймні надію на можливість систематизації пережитого. Герой спочатку вказує на деталі зовнішнього простору, в якому знайшов собі прихисток з пером в руках, щоб мати змогу поринути у стихію письма. Прикметно, що кімната в Парижі нагадує герою його кімнату в Мальтаверне - завдяки чому Ален одночасно і дистанціюється від простору свого минулого, і відчуває необхідний комфорт для роботи письма. «Вікно іiі дивиться в вузький садок готелю "Есперанс" на вулиці Вожірар, проти семінарії кармелітів. Гомін Парижа глухіший, ніж гомін сосен у парку під диханням бур у пору рівнодення; я спокійний, я не страждаю» [8, с. 187]. Герой-оповідач в характеристиках урбаністичного простору відштовхується від природніх локусів краю свого дитинства, у такий спосіб вписуючи природу Мальтаверне в свою «перцепційну форму» міста. Спокою Алену надає сама думка про те, що в Парижі його ніхто не знає, завдяки чому він почуває себе безіменним. У світлі минулого, яке він має переосмислити, i від якого - у певному розумінні - звільнитися, стає зрозумілою потреба героя у творенні нового Себе. Як юнаки 3 романів Бальзака, він входить у Париж з метою почати нове життя і на початковому етапі живе у районі, головним мотивом опису якого $є$ тиша (алюзія на квартал, де мешкав Растіньяк у «Батькові Горіо»). На відміну від Растіньяка, Ален не прагне дійти до вершини світу — йому важливіше повернутися до себе справжнього, а тому вибір помешкання на вулиці Вожирар набуває додаткових конотацій. Знаменита поміж іншим музеєм загублених речей (одним 3 найбільших у Європі і найстаріших у світі) вулиця Вожирар стає прикладом того, що топоніми урбаністичного простору виконують у просторі письма про Себе функцію метафори: і виражають глибинні пошуки героя, і пояснюють спрямованість його естетичної роботи. Ален не втомлюється перераховувати маршрути своїх піших прогулянок, в яких зливається 3 потоком людей, підпадаючи, за його словами, під «чаклунську силу» Парижа. Як Рафаель Бальзака, герой Моріака ритуально переходить на інший бік Сени. «Паризькі вулиці варті всіх музеїв» $[8$, c. 202], - у топографію Алена входять твори літера- тури (імена письменників зринають біля топонімів), входить історія (місця визначних подій) - i письмо про місто починає нагадувати крамничку антиквара 3 «Шагреневої шкіри». Ален усвідомлює, що історія, відображена в топонімах Парижа, звернена не лише у минуле, а й у прийдешнє - топографія як складова простору письма про Себе відкриває орієнтованість героя Моріака на майбутнє: «я думаю про те, що зріє в цій Ліліпутії 1907 року і що мені судилося побачити...» [8, с. 203].

У письмі фікційного суб'єкта роману початку XXI ст. топографія промовляє більше, ніж мовчання героя.

В романі Д. Пенака «Щоденник тіла» зникає топонімічна конкретика, але продовжується започаткована літературою XVIII ст. традиція поєднання внутрішнього стану людини 3 елементом урбаністичного простору. Герой Пенака, який звик усі зміни в своєму житті передавати через образи тіла, екстраполює усвідомлення процесу старіння на враження від міста. Перенесення героєм свого настрою на міський простір породжує надміру лаконічний запис у щоденнику: «Схоже, сама вулиця вирішила вести щоденник тіла» [10, с. 186]. Без пояснень, розшифрувань, контексту щоденниковий запис, що фактично є поетикальною фігурою (здійснюється спроба олюднити вулицю), наближається до хайку (суб'єкт письма замикає те, що бачить та почуває, вузьким горизонтом слів). Цим записом герой Пенака спонукає у реципієнта створення уявного образу людини, що дуже близька до образу, про який, за словами Р. Барта, мріє більшість: «скільки західних читачів мріяли так прогулюватися по життю з блокнотиком в руці, відмічаючи тут і там певні “враження”, стислість яких була б гарантією досконалості, а простота - критерієм глибини» [3, с. 158]. У цій спробі топографії в щоденнику тіла має місце заперечення «розгортання», про що пише Р. Барт, інтерпретуючи хайку. Звуження запису до одного речення-фігури у випадку фіксування перцептивної формули міста на противагу поширеним записам на тему тіла продиктоване бажанням героя Пенака відділити тілесне від психологічного. Не переходячи на опис, стираючи власне «Я» 3 цього запису, фіксуючи графічно погляд, герой передає свої переживання, про яке не мав наміру писати, в щоденник тіла вулиці. Стилізація під хайку дозволяє суб'єкту письма уникнути непрозорості смислу в цьому записі - розтікання смислу в сфері символів, замикання його на собі. Фігуративність письма за манерою хайку всупереч стратегіï homo scribens Пенака не дозволяє реалізуватися плану відділення тілесного від психологічного. 
Топографія Карла з роману П. Кіньяра «Салон у Вюртенберзі» $€$ інтертекстом до тлумачення функціонального значення міста в письмі героя-романтика. На це вказує локус саду у місті, що контрапунктом проходить крізь письмо Карла. Згадки про міський простір, що покликані створити для мнемографії героя необхідні координати іiі розгортання, зводяться до будинку з садом в Сен Жерменан-Ле. Усі інші топоніми, що виринають у просторі письма Карла, насаджуються на семантичне осердя топографії, розгорнутої зі спогадів про СенЖермен-ан-Ле. Кожен будинок, до якого тяжіє опис міського простору і яким він обмежується, має біля себе сад, що для героя асоціюється з раєм. Своєю топографічною манерою герой Кіньяра викриває ностальгію за дружніми стосунками, любов до того минулого, що мало місце в закріплених на письмі координатах міських декорацій - ті почуття та внутрішні стани, які не може назвати / визнати 3 причин їх втрати. Письмо ж виступає наслідком переміщення-віднайдення смислів подій.

Всі герої аналізованих творів звертаються до практики письма як подорожі-повернення, через яку реалізується загострення оптичного фокусу. В тексті-письмі досвід постає не точкою відліку, а результатом письмової оповіді. Пережите вимагає від героїв оформлення та, відповідно, пізнання. За допомогою письма фікційні суб'єкти формують свій досвід, а віртуальний реципієнт включається у цей процес як повноправний учасник, тож замість поради від героя він отримує практику піклування про Себе.

Чи не найцікавіший модус переміщення презентує рівень оповіді. Герої-оповідачі текстів-письма акцентують питання неможливості зізнання як такого, позаяк суб' єкт, що береться за перо, шукає — а не знає наперед - яким він $є$. Усі знання про себе, що передують письму, формують події зовнішнього світу, від якого герой відходить, обираючи роль суб'єкта письма. Сам факт письма свідчить: відношення героя 3 пером у руках до протагоніста виписуваних подій передають слова: я не такий, я є іншим. Беру-

\section{REFERENCES}

1. Barthes, Roland. Oeuvres complètes (nouv. éd. en cinq volumes, revue, corrigée et présentée par Éric Marty). Paris: Seuil, 2002.

2. Blanchot, Maurice. «Le journal intime et le récit». An Le livre à venir. Paris: Gallimard, 1959: 253-259.

3. Boulle, Pierre. La planète des singes. Paris: Julliard, 1963. чи на себе роль суб'єкта письма, герой виявляється включеним у процес вироблення смислів пережитих подій, що уможливлюється завдяки лінії письма. Таким чином, сповідь не може бути складовою стратегії письма про Себе, натомість сповідальність $€$ маркером відношення утворюваного письмом простору до «Я» (героя, оповідача, оновленого суб'єкта в процесі становлення — всіх в одному).

Аналіз героя в естетичній діяльності письма про Себе дозволив пояснити, що тканина письма плететься з петель, які зв'язує становлення нового суб'єкта 3 читачем як зовнішнім Іншим, а через нього, з собою минулим та теперішнім. Метаморфози суб' єктивності можна назвати однією з головних характеристик тексту-письма: трансформація персонажа історії зовнішнього життя на героя свого власного тексту пережитих подій, на оповідача про Себе, на розсіяного суб'єкта письма.

Аналіз homo scribens як героя в естетичній діяльності письма про Себе підводить до думки про трансгресію, притаманну природі письма, в якій відбувається творення оновленого «Я». В роботі суб'єктів письма нівелюється жест розриву зовнішнього та внутрішнього, есплікується буття відмінності [6]. Письмо персонажів, що починається з потреби героя у порятунку «Я» суб'єкта, що пише, поза спрямованістю [2] виявляється творенням світу, досягненням недосяжного, переходом через непрохідне.

Роман початку XXI ст., граючись претекстами минулих епох, утверджує відкритість письма як оповідної моделі до широкого діапазону тем та проблем, які не можливо вичерпати. Ера інтернету вносить кардинальні зміни в життя людини, що неодмінно позначиться на романному просторі. Новим горизонтом цього дослідження може стати аналіз письма як оповіді $з$ особливою комунікативною аркою в мобільному романі, інтернет-романі тощо. Нові технології вплинуть на розуміння класичних історій, і письмо про Себе зможе відкрити інші свої грані, адже переміщення складових елементів художнього простору, визначеного роботою письма фікційного суб’єкта, є чи не єдиною його константою.

4. Deleuze, Gilles. Différence et Répétition. Paris: éditions P.U.F., 1968.

5. Eco, Umberto. L'oeuvre ouverte. Traduit par : Chantal Roux de Bézieux, André Boucourechliev. Paris: Points Essais, 2015.

6. Foucault, Michel. «SelfWriting». In Ethics: Subjectivity and Truth. V. 1. Translated by Robert Hurley and 
others. New-York: The New Press, 1997: 207223. https://monoskop.org/images/0/00/Foucault Michel_Ethics_Subjectivity_and_Truth.pdf

7. Lejeune, Phillipe. On Autobiography, The Autobiographical Pact, Autobiographical Contract. Minneapolis: University of Minnesota Press, 1989. https://edocs.uis.edu/Departments/LIS/ Course Pages/LNT501/RN/R

8. Mauriac, François. Un adolescent d'autrefois. Paris: Flammarion, 1982.
9. Gary, Alexandre Diego. S. ou l'espérance de vie, Paris: Gallimard, 2009, 169 p.

10. Pennac, Daniel. Journal d'un corps. Paris: Gallimard, 2012.

11. Richard, Jean-Pierre. Pages Paysages. Microlectures II. Paris: Éditions du Seuil, 1984.

12. Verne, Jules. Vingt mille lieues sous les mers. https://fr.wikisource.org/wiki/ Vingt_mille_lieues_sous_les_mers

\title{
MODES OF MOVEMENT IN FICTIONAL SUBJECT'S SELF-WRITING
}

\author{
Yuliia Pavlenko \\ pavlenkoyulia1@gmail.com \\ https://orcid.org/0000-0003-4157-2550 \\ Doctor of Sciences (Philology), Professor, Department of Theory and History of \\ World Literature named after Professor V.I. Fesenko, Kyiv National Linguistic University
}

\begin{abstract}
This article explains the Modes of movement in the fictional landscape of the character's letter about himself. It offers the notion of the self-writing of the fictional subject as one that allows the reader to see the peculiarities of the text as a whole, the fictional landscape of which is the character's letter.

The analysis offered confirms the efficiency of the methodology of micro-reading for the investigation of the fictional subject's letter. The study of the letter about oneself is a topic of the French novel that gives the opportunity to demonstrate its functioning on the different levels of the piece of fiction.

The analysis of self-writing on the level of metaphorical originality demonstrates the functional meaning of the personal letter as the body of the refreshed subject, the itinerary of his learning and his home, and the metaphors of water, fire, air and earth help to articulate the meanings of the letter without mentioning its specific titles.

Within the interaction of the personal letter and the novel, the character-narrator's self-writing creates a multiplicity which Deleuze associates with the rhizome. The process of multiplicity operates on every textual level of the novel. On the historical level (according to J. Jannet) the plot tells one thing, but with the help of the letter's narration modus, new elements are added, creating another, different story. The self-writing confirms that the story does not coincide with the plot, as the character relates to his past (more or less distant in time), but the letter creates his present. The genre models of the fictional character's self-writing also find themselves inside the rhizome maze. Moreover, multiplicity even examines physicality: from negation to formation.

Renouncing a climax and changing the mechanism of intrigue are characteristic for this type of fictional structure of the letter-novel (self-writing). A new meaning is formed with the help of a specific description of life episodes. This new meaning is made possible due to the constructive meeting of the character (in the past), the character-narrator, the subject of the letter (in the present) from the new aspect of his ego, and addressing another ego, the person who will be reborn with the help of the letter (in the future).

With the help of fictional self-writing, subjects form their experience and the virtual recipient is included in this process as a participant enjoying full rights. Thus, instead of receiving advice from the character, he acquires practice in caring for himself.

The real reader of novels, whose fictional space is determined by the work of homo scribens, is included in the communicative arch of self-writing. The personal letter about oneself is a journey into the depths of the true essence of the man and the creation of the map of subjectivity and initiation. The method of self-writing leads inevitably to the path of the harmonization of the subject's own ego.
\end{abstract}

Key words: French novel; metaphor; self-writing; displacement; fictional subject; homo scribens; journey; Gary; Mauriac; Pennac. 